\title{
Performance of banana genotypes with resistance to black leaf streak disease in Northeastern Brazil
}

\author{
Olmar Baller Weber(1), Deborah dos Santos Garruti(1), \\ Normândia Pereira Norões ${ }^{(2)}$ and Sebastião de Oliveira e Silva(3)
}

\begin{abstract}
(1)Embrapa Agroindústria Tropical, Rua Dra. Sara Mesquita, no 2.270, Planalto do Pici, CEP 60511-110 Fortaleza, CE, Brazil. E-mail: olmar.weber@embrapa.br, deborah.garruti@embrapa.br ${ }^{(2)}$ Frutacor, Distrito Irrigado de Jaguaribe-Apodi, Quadra 02, s/no, CEP 62930-000

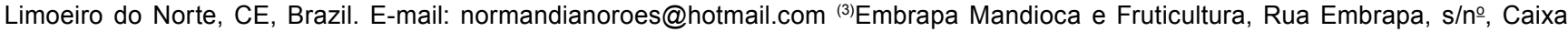
Postal 007, CEP 44380-000 Cruz das Almas, BA, Brazil. E-mail: ssilva3000@gmail.com
\end{abstract}

\begin{abstract}
The objective of this work was to evaluate the growth and the production of banana plants with resistance to black leaf streak disease (BLSD), in comparison with the performance of traditional cultivars susceptible to the disease. Twenty cultivars were planted at the Jaguaribe-Apodi plateau, in Northeastern Brazil: 15 with resistance to BLSD, namely Pacovan Ken, PV42-68, BRS Vitória, BRS Japira, BRS Preciosa, BRS Garantida, Thap Maeo, BRS Tropical, BRS Platina, BRS Maravilha, FHIA 02, FHIA 18, Galil 18, Caipira, and Buccaneer; and five susceptible to the disease, namely Williams, Grande Naine, Pacovan, Prata Anã, and Maçã. Banana growth and production of bunches were evaluated during three successive cycles. 'BRS Tropical' and 'Caipira' can replace 'Maçã', which is very susceptible to Fusarium wilt. The BRS Maravilha, BRS Platina, FHIA 02, FHIA 18, and Galil 18 cultivars show adequate height and high yield potential, being alternatives to the traditional Prata subgroup. The Buccaneer cultivar is an alternative to the susceptible cultivars of the Cavendish subgroup and can be explored in an irrigated agrosystem.
\end{abstract}

Index terms: Musa, Mycosphaerella fijiensis, banana cultivars, black leaf streak disease.

\section{Desempenho de genótipos de bananeira com resistência à sigatoka-negra no Nordeste brasileiro}

\begin{abstract}
Resumo - O objetivo deste trabalho foi avaliar o crescimento e a produção de bananeiras com resistência à sigatoka-negra, em comparação ao desempenho de cultivares tradicionais suscetíveis à doença. Vinte cultivares foram plantadas no planalto Jaguaribe-Apodi, no Nordeste do Brasil: 15 com resistência à sigatokanegra, a saber, Pacovan Ken, PV42-68, BRS Vitória, BRS Japira, BRS Preciosa, BRS Garantida, Thap Maeo, BRS Tropical, BRS Platina, BRS Maravilha, FHIA 02, FHIA 18, Galil 18, Caipira e Buccaneer; e cinco suscetíveis à doença, a saber, Williams, Grande Naine, Pacovan, Prata Anã e Maçã. O crescimento e a produção de cachos das bananeiras foram avaliados durante três ciclos sucessivos. 'BRS Tropical' e 'Caipira' podem substituir 'Maçã', que é bastante suscetível à murcha de Fusarium. As cultivares BRS Maravilha, BRS Platina, FHIA 02, FHIA 18 e Galil 18 apresentam porte adequado e alto potencial de rendimento, sendo alternativas ao tradicional subgrupo Prata. Já a cultivar Buccaneer é alternativa às cultivares suscetíveis do subgrupo Cavendish e pode ser explorada em agrossistema irrigado.
\end{abstract}

Termos para indexação: Musa, Mycosphaerella fijiensis, cultivares de bananeira, sigatoka-negra.

\section{Introduction}

Banana (Musa spp.) plants are widely cultivated in tropical regions, and developing countries account for over a third of global banana production (FAO, 2016), generating opportunities and income for producers and other agents in the fresh fruit value chain. In Brazil, the banana crop is spread throughout all regions, with an annual harvest of 7 million tons. The Northeast of the country represents nearly $40 \%$ of the planted area and $35 \%$ of the national production (IBGE, 2015). However, despite the high production levels in this particular region, fruit yield is still low $\left(<13 \mathrm{Mg} \mathrm{ha}^{-1}\right)$, which is associated with the productivity potential of traditional cultivars, such as Prata (Donato et al., 2009), compared with other types of banana.

The banana cultivars traditionally planted in Brazil are susceptible to Panama disease and Sigatoka leaf spot disease (Silva et al., 2015). In addition, inadequate cultivation practices are often adopted, in particular 
planting under rainfed conditions in semiarid regions. In irrigated areas, for example, the Prata cultivar can produce fruit yields of up to $40 \mathrm{Mg} \mathrm{ha}^{-1}$ (Donato et al., 2009), which can easily be exceeded by the cultivars of the Cavendish subgroup, mainly destined for the export market, such as Grande Naine. This cultivar produced 70 to $75 \mathrm{Mg} \mathrm{ha}^{-1}$ per year under irrigation and a dense spacing of 2,000 to 4,000 plants per hectare (Flori et al., 2004). It should be noted, however, that consumers in Northeastern Brazil show a preference for 'Prata', 'Maçã' (Matsuura et al., 2004), and 'Pacovan' (Garruti et al., 2012) bananas.

Several different diseases infect banana plants, but, of all fungal infections, black leaf streak disease (BLSD), also known as black Sigatoka, is considered to be the worst, due to its widespread occurrence in many countries, its severe negative impact on banana production (Robert et al., 2012), and its effects on cultivars belonging to different genomic groups (Churchill, 2011). In Brazil, BLSD causes significant losses in the humid areas of the Amazon (Gasparotto et al., 2006), affecting bananas of the 'Prata' and 'Cavendish' subgroups (Silva et al., 2014). The disease spreads through the spores of the fungus Mycosphaerella fijiensis (Silva et al., 2014), which could happen during the transport of banana plant material that could contain the pathogen propagules, causing concern in the banana agribusiness. As a result, strategies for the genetic improvement and the development of cultivars resistant to BLSD are being sought in Brazil (Silva et al., 2013).

No occurrences of BLSD have been reported in Northeastern Brazil to date. However, this can be a matter of time, since, during certain times of the year, the climatic conditions of some banana-producing areas are favorable to the development of the disease, with air temperatures of approximately $27^{\circ} \mathrm{C}$ and high relative humidity of around $80 \%$ (Ghini et al., 2007; Jesus Júnior et al., 2008). Because of this, some researches on genotypes resistant to BLSD (Silva et al., 2015) and on cultivars tested in semiarid conditions (Lédo et al., 2008; Azevedo et al., 2010) are already being carried out. However, the plant size and the productive capacity of cultivars resistant to BLSD may not be suitable for growing in open coastal areas.

The objective of this work was to evaluate the growth and the production of banana plants with resistance to BLSD, in comparison with the performance of traditional cultivars susceptible to the disease.

\section{Materials and Methods}

A total of 20 banana cultivars were evaluated: 15 considered resistant to BLSD, namely, Pacovan Ken, PV42-68, BRS Vitória, BRS Japira, BRS Preciosa, BRS Garantida, Thap Maeo, BRS Tropical, BRS Platina, BRS Maravilha, FHIA 02, FHIA 18, Galil 18, Caipira, and Buccaneer; and five susceptible to the disease, namely, Williams, Grande Naine, Pacovan, Prata Anã, and Maçã. The experiment was set up at the Frutacor farm, located in the irrigation district of Jaguaribe-Apodi, in the Jaguaribe-Apodi plateau, in the municipality of Limoeiro do Norte, in the state of Ceará, Brazil $\left(05^{\circ} 20^{\prime} \mathrm{S}, 38^{\circ} 05^{\prime} \mathrm{W}\right.$, at $80 \mathrm{~m}$ above sea level). The climate of the area is hot and semiarid, BSw'h' according to Köppen-Geiger (DNOCS, 2016). During the experimental period, the average temperature at the farm was $26.4 \pm 1.2^{\circ} \mathrm{C}$, the relative humidity was $73.4 \pm 8.8 \%$, and the average wind speed was $5.8 \pm 0.6 \mathrm{~m} \mathrm{~s}^{-1}$. The soil of the experimental area was classified as an Inceptisol, and the $0-20 \mathrm{~cm}$-depth, according to the analytical methods of Silva (2009), showed: $\mathrm{pH}\left(\mathrm{H}_{2} \mathrm{O}\right) 7.1$ (ratio of 1:2.5); $18.8 \mathrm{mg} \mathrm{kg}^{-1} \mathrm{P}$, $20.4 \mathrm{mmol}_{\mathrm{c}} \mathrm{kg}^{-1} \mathrm{~K}, 1.3 \mathrm{mmol}_{\mathrm{c}} \mathrm{kg}^{-1} \mathrm{Na}, 4.9 \mathrm{mg} \mathrm{kg}^{-1} \mathrm{Cu}$, $10.6 \mathrm{mg} \mathrm{kg}^{-1} \mathrm{Fe}, 55.8 \mathrm{mg} \mathrm{kg}^{-1} \mathrm{Mn}$, and $2.0 \mathrm{mg} \mathrm{kg}^{-1} \mathrm{Zn}$ extracted with Mehlich-1; and $79.7 \mathrm{mmol}_{\mathrm{c}} \mathrm{kg}^{-1} \mathrm{Ca}$ and $1.3 \mathrm{mmol}_{\mathrm{c}} \mathrm{kg}^{-1} \mathrm{Mg}$ extracted with $1 \mathrm{~mol} \mathrm{~L}^{-1} \mathrm{KCl}$.

The preparation of the area consisted of soil plowing, harrowing, and furrowing (0.4-m depth and 2 or $4 \mathrm{~m}$ apart). Bovine manure (12 L per plant) was placed in the furrows, along with $300 \mathrm{~g}$ per plant of monoammonium phosphate, $200 \mathrm{~kg} \mathrm{ha}^{-1} \mathrm{P}_{2} \mathrm{O}_{5}$, and $100 \mathrm{~kg} \mathrm{ha}^{-1} \mathrm{~N}$. These fertilizer dosages are commonly used for planting banana seedlings in the irrigation district of Jaguaribe-Apodi. After the furrows were closed and the soil incubated for a month, hose pipes and Gyronet micro-sprinklers (Netafim Brasil, Ribeirão Preto, SP, Brazil) were installed, with a flow rate of $40 \mathrm{~L}$ per hour and a wetting diameter of $4 \mathrm{~m}$. On sunny days, up to $53 \mathrm{~L}$ of water per plant per day were used throughout the experimental period.

Micropropagated seedlings were planted (Table 1), which were initially acclimatized in 1-L capacity plastic bags, containing a mixture of vermicompost, soil, and washed sand (in a 1:6:3 ratio by volume), under a black shade cloth to reduce luminosity from sunlight in $25 \%$. The substrate, according to the analytical methods of Silva (2009), showed: $\mathrm{pH}\left(\mathrm{H}_{2} \mathrm{O}\right)$ 7.3 (ratio of 1:2.5); $43.8 \mathrm{mg} \mathrm{kg}^{-1} \mathrm{P}, 7.5 \mathrm{mmol}_{\mathrm{c}} \mathrm{kg}^{-1} \mathrm{~K}$, 
$2.1 \mathrm{mmol}_{\mathrm{c}} \mathrm{kg}^{-1} \mathrm{Na}, 0.4 \mathrm{mmol}_{\mathrm{c}} \mathrm{kg}^{-1} \mathrm{Cu}, 29.7 \mathrm{mg} \mathrm{kg}^{-1} \mathrm{Fe}$, $43.1 \mathrm{mg} \mathrm{kg}^{-1} \mathrm{Mn}$, and $2.1 \mathrm{mg} \mathrm{kg}^{-1} \mathrm{Zn}$ extracted with Mehlich-1; and 49.6 mmol $_{\mathrm{c}} \mathrm{kg}^{-1} \mathrm{Ca}$ and 18.9 mmol $_{\mathrm{c}} \mathrm{kg}^{-1}$ $\mathrm{Mg}$ extracted with $1 \mathrm{~mol} \mathrm{~L}^{-1} \mathrm{KCl}$. In April 2008, when planting was performed in the field, the seedlings with root clods had more than $30 \mathrm{~cm}$ of shoot height. For the distribution of the seedlings of the 20 evaluated cultivars, a randomized complete block design was used, with three replicates with 20 plants. The spacing between planting rows was 2 and $4 \mathrm{~m}$, and between plants in the row was $2.5 \mathrm{~m}$. Seedlings of the Prata Catarina cultivar were planted in the external borders.

Thirty days after planting, ferti-irrigation of the banana plants began. Every three days, on average, low doses of urea $(45 \% \mathrm{~N})$, potassium sulphate $(18 \% \mathrm{~S}$ and $\left.50 \% \mathrm{~K}_{2} \mathrm{O}\right)$, and potassium chloride $\left(60 \% \mathrm{~K}_{2} \mathrm{O}\right)$ were provided, totaling almost $270 \mathrm{~kg} \mathrm{ha}^{-1} \mathrm{~N}, 21 \mathrm{~kg} \mathrm{ha}^{-1} \mathrm{~S}$, and $233 \mathrm{~kg} \mathrm{ha}^{-1} \mathrm{~K}_{2} \mathrm{O}$ in the first year. The management of the fertilizers and of the cultivation practices was carried out in alignment with the recommendations of Borges et al. (2009).

When bunches first appeared, the height and diameter of the pseudostem were measured at about $30 \mathrm{~cm}$ from the base, and the number of green leaves on 12 central plants per plot were counted. Data collection was programmed according to the appearance of bunches. For this, bunches were cut, the hands and fingers were separated, and their fresh weight was determined in order to calculate the production of bunches without stalks. In addition, in order to calculate the production cycles, the period of time between the planting of seedlings in the field and the harvest of bunches was noted.

Banana growth and production data were analyzed in a randomized complete block design, in a split-plot arrangement. The plots were considered the banana

Table 1. Traits of the banana (Musa spp.) cultivars planted at the Frutacor farm, in the municipality of Limoeiro do Norte, in the state of Ceará, Brazil.

\begin{tabular}{|c|c|c|c|c|}
\hline Cultivar & Group & Subgroup & Genealogy (origin) $^{(1)}$ & Sensibility to plant diseases \\
\hline Pacovan Ken & AAAB & Prata & Pacovan hybrid (AAB) x M 53 (AA) from Embrapa, Brazil & Resistant to BLSD, YS, and Fusarium wilt ${ }^{(2)}$ \\
\hline PV42-68 & $\mathrm{AAAB}$ & Prata & Pacovan hybrid (AAB) x M 53 (AA) from Embrapa, Brazil & Resistant to BLSD, YS, and Fusarium wilt ${ }^{(2)}$ \\
\hline BRS Vitória & AAAB & Prata & Pacovan hybrid (AAB) x M 53 (AA) from Embrapa, Brazil & Resistant to BLSD, YS, and Fusarium wilt ${ }^{(2)}$ \\
\hline BRS Japira & $\mathrm{AAAB}$ & Prata & Pacovan hybrid (AAB) x M 53 (AA) from Embrapa, Brazil & Resistant to BLSD, YS, and Fusarium wilt ${ }^{(2)}$ \\
\hline BRS Preciosa & $\mathrm{AAAB}$ & Prata & Pacovan hybrid (AAB) x M 53 (AA) from Embrapa, Brazil & Resistant to BLSD, YS, and Fusarium wilt ${ }^{(2)}$ \\
\hline BRS Garantida & $\mathrm{AAAB}$ & Prata & Prata São Tomé hybrid from Embrapa, Brazil & Resistant to BLSD, YS, and Fusarium wilt ${ }^{(2)}$ \\
\hline Thap Maeo & $\mathrm{AAB}$ & Mysore & Mysore-type cultivar from Thailand and Embrapa, Brazil & Resistant to BLSD, YS, and Fusarium wilt ${ }^{(2)}$ \\
\hline BRS Tropical & AAAB & Prata & Yangambi hybrid $02 \times \mathrm{M}$ & $\begin{array}{c}\text { Moderately resistant to BLSD, YS, and Fusarium } \\
\text { wilt }\end{array}$ \\
\hline BRS Platina & AAAB & Prata & Prata Anã hybrid (AAB) x M53 (AA) from Embrapa, Brazil & Resistant to BLSD, YS, and Fusarium wilt \\
\hline BRS Maravilha & $\mathrm{AAAB}$ & Prata & Prata Anã hybrid (AAB) x SH31-42 (AA) from & $\begin{array}{l}\text { Resistant to BLSD and Fusarium wilt, and } \\
\text { moderately resistant to YS }\end{array}$ \\
\hline FHIA $02^{(4)}$ & AAAB & Prata & FHIA hybrid from Embrapa, Brazil & Resistant to BLSD, YS, and Fusarium wilt \\
\hline FHIA 18 & AAAB & Prata & FHIA hybrid from Embrapa, Brazil & $\begin{array}{l}\text { Resistant to BLSD, moderately resistant do YS, } \\
\text { and susceptible to Fusarium } \text { wilt }^{(2)}\end{array}$ \\
\hline Galil 18 & AAAB & Prata & FHIA hybrid from Multiplanta, Brazil & Resistant to BLSD ${ }^{(5)}$ \\
\hline Buccaneer & AAAA & $\begin{array}{l}\text { Gros } \\
\text { Michel }\end{array}$ & High Gate hybrid from Jamaica and Embrapa, Brazil & Resistant to BLSD, YS, and Fusarium wilt \\
\hline Caipira & AAA & Ibota & Cultivar from Embrapa, Brazil & Resistant to BLSD, YS, and Fusarium wilt \\
\hline Pacovan & AAB & Prata & Cultivar from Embrapa, Brazil & $\begin{array}{l}\text { Susceptible to BLSD and YS, and moderately } \\
\text { susceptible to Fusarium } \text { wilt }^{(2)} \text { (Foc, race 1). }\end{array}$ \\
\hline Prata Anã & $\mathrm{AAB}$ & Prata & Cultivar from Embrapa, Brazil & $\begin{array}{l}\text { Susceptible to BLSD and YS, and moderately } \\
\text { susceptible to Fusarium wilt }{ }^{(2)} \text { (Foc, race 1) }\end{array}$ \\
\hline Maçã & $\mathrm{AAB}$ & Prata & Cultivar from Embrapa, Brazil & $\begin{array}{l}\text { Susceptible to BLSD and Fusarium wilt }{ }^{(3)} \text {, and } \\
\text { moderately resistant to } \mathrm{YS}^{(5)}\end{array}$ \\
\hline Williams & AAA & Cavendish & Cultivar from Embrapa, Brazil & $\begin{array}{l}\text { Susceptible to BLSD and YS, and resistant to } \\
\text { Fusarium wilt }{ }^{(3)} \text { (Foc, race 1) }\end{array}$ \\
\hline Grande Naine & AAA & Cavendish & Cultivar from Embrapa, Brazil & $\begin{array}{l}\text { Susceptible to BLSD and YS, and resistant to } \\
\text { Fusarium wilt }{ }^{(3)} \text { (Foc, race 1) }\end{array}$ \\
\hline
\end{tabular}

${ }^{(1)}$ Embrapa, Empresa Brasileira de Pesquisa Agropecuária (Brazil); and Multiplanta, Multiplanta Tecnologia Vegetal Ltda. ${ }^{(2)}$ According to Borges et al. (2009). ${ }^{(3)}$ According to Cunha et al. (2015). ${ }^{(4)}$ FHIA 02 belongs to the Prata subgroup (Jesus et al., 2013). ${ }^{(5)}$ According to Costa et al. (2012). BLSD, black leaf streak disease; YS, yellow Sigatoka; and Foc, Fusarium oxysporum f. sp. cubense fungus. 
cultivars, and the subplots, the production cycle. Data were subjected to the analysis of variance (Anova) using the Sisvar software, version 5.6 (Universidade Federal de Lavras, Lavras, MG, Brazil), and the means of treatments were grouped by the Scott-Knott test, at $5 \%$ probability. The means of the variables for all three cycles were subjected to ascending hierarchical classification (AHC), using the Euclidean distance matrix as a measure of dissimilarity and the unweighted pair-group method with arithmetic mean (UPGMA) for the formation of clusters (Sneath \& Sokal, 1973). The variable "cycle" was considered as the number of days between planting and harvest of the first bunch, assuming that the later cycles would be affected by the thinning of banana plants. Moreover, to help define and select genotypes with the desired agronomic traits, the same data matrix was subjected to Pearson's multivariate principal component analysis (PCA) and to a correlation biplot with the automatic coefficients. AHC and PCA were performed by computing the data matrix (Abdi \& Williams, 2010) with the XLSTAT software, version 2015.3.01 (Addinsoft, Inc., Brooklyn, NY, USA).

\section{Results and Discussion}

A vigorous aerial growth and a satisfactory production of bunches were observed for 19 of the evaluated cultivars (Tables 2 and 3). The exception was 'Maçã', for which only a few small bunches were obtained due to the incidence of Fusarium wilt caused by the fungus Fusarium oxysporum f. sp. cubense (Foc). This result was expected in the areas that had been occupied five years before by banana plants of the Maçã cultivar. Although the BRS Platina, BRS Tropical, BRS Garantida, and Grande Naine cultivars were planted in neighbor plots to Maçã, no symptoms of the disease were detected, confirming the resistance of those plants to Foc, possibly race one. The cultivars Grande Naine and Williams from the Cavendish subgroup are susceptible to Foc, race TR4 (Ploetz, 2015), for which there are no known reports in the area, still considered under risk. Among the genotypes tested, 'BRS Tropical', 'Thap Maeo', and 'Caipira', also resistant to Fusarium wilt, produce small fruits and can be considered as a type of 'Maçã' banana (Carvalho et al., 2011).
In relation to yellow Sigatoka (YS), no control measures were adopted in the experimental area. Although the disease has been controlled in the surrounding banana plantations, this did not prevent the emergence of mild symptoms of YS on older leaves of the Pacovan, Prata Anã, William, and Grande Naine cultivars. The tested materials did not exhibit symptoms of BSLD, however. It should be pointed out that the local climatic conditions are favorable to the emergence of BLSD, according to Guini et al. (2007) and Jesus Júnior et al. (2008), with milder temperatures from 25 to $27^{\circ} \mathrm{C}$ during April and May (rainy season) and a high relative humidity of $>75 \%$. Besides, the Jaguaribe-Apodi plateau, where the experiment was carried out, is not very far (just over $1,000 \mathrm{~km}$ ) from the productive areas of the Amazon region, where BLSD appears to be endemic.

Data on the growth and production of all studied cultivars, except Maçã, were subjected to Anova, and an interaction between cultivars and cycles was observed $(\mathrm{p}<0.05)$ (Tables 2 and 3). Cultivars with different genealogy (Table 1) are expected to show a different performance even when uniform-sized plantlets are planted in the field. The Pacovan Ken, PV42-68, BRS Victoria, BRS Japira, BRS Preciosa, and BRS Garantida cultivars grew to be tall, measuring $5.8 \mathrm{~m}$ from the base to the insertion of the bunch, especially in the third cycle, together with the traditional cultivar Pacovan (Table 2); therefore, they are not recommended for crops grown in plateaus without windbreak protection. The Thap Maeo cultivar was also considered unsuitable, showing average height ranging from $3.5 \mathrm{~m}$, in first cycle, to $5.1 \mathrm{~m}$, in the third cycle, besides a thin pseudostem in the early cycles of bunch production. This banana plant cultivar is also subject to pseudostem drop at the bunch insertion point. It should be highlighted that, during the experiment, winds reached $9.17 \mathrm{~m} \mathrm{~s}^{-1}$ in February 2009 and $9.26 \mathrm{~m} \mathrm{~s}^{-1}$ in January 2010. Winds rated as force 4 (5.5 to $7.9 \mathrm{~m} \mathrm{~s}^{-1}$ ) according to Beaufort's scale can already cause minor damage to leaves, but, in the Jaguaribe-Apodi plateau, winds reaching force 6 (10.8 to $13.8 \mathrm{~m} \mathrm{~s}^{-1}$ ) occasionally occur.

Regarding the size of the banana plant, the following cultivars were selected: BRS Tropical, derived from Yangambi 02; BRS Platina and BRS Maravilha, both derived from Prata Anã; the FHIA cultivars, i.e., FHIA 02, FHIA 18, Galil 18, or false FHIA 18; and 
Buccaneer and Caipira, whose pseudostems did not exceed $4.3 \mathrm{~m}$ in height (Table 2). A lower plant height was accompanied by a greater pseudostem diameter, except for the Caipira cultivar, during the second and third production cycles. The green leaves varied between banana cultivars and cycles, but overall they were satisfactory when bunches first appeared. In general, shorter cultivars have a wider pseudostem that better supports the bunches, which is desirable for banana plantations on irrigated plateau areas, together with a large number of leaves that enable a greater banana production (Nomura et al., 2013).

The production of banana hands and fruits was affected by the interaction of cultivars and cycles (Table 2). 'BRS Garantida', 'BRS Tropical', and 'Caipira' produced fewer hands during the first cycle, similarly to 'Prata Anã'. In turn, the Thap Maeo cultivar showed the greatest potential to produce hands and fruits in the bunch during the second and third cycles, 13 and 19 months after the seedlings were planted, respectively. The last period covers the three production cycles, for which the BRS Tropical, BRS Maravilha, FHIA 02, FHIA 18, Galil 18, Caipira, and Prata Anã cultivars showed similar results. Unlike the second and third cycles, which were in part affected by thinning and scheduled harvest, the first cycle has been used as an indicator of precocity for banana production. The harvest time of the first banana bunches was quite short ( $>9$ months) for the BRS Maravilha, FHIA 02, FHIA 18, and Buccaneer cultivars (Table 3). However, this precocity was also a notable feature in 'BRS Preciosa' and 'BRS Garantida', both tall, and in 'Thap Maeo'. Longer production cycles have been reported for banana cultivars under irrigation in other

Table 2. Plant height from the ground up to the point of emission of the bunch (BPH), diameter of the base of the pseudostem (PD), number of green leaves at the flowering stage (GLN), and number of hands (HN) and of fruits in the bunch (FN) of banana (Musa spp.) cultivars planted at the Frutacor farm, in the municipality of Limoeiro do Norte, in the state of Ceará, Brazil $^{(1)}$.

\begin{tabular}{|c|c|c|c|c|c|c|c|c|c|c|c|c|c|c|c|}
\hline \multirow{2}{*}{$\begin{array}{l}\text { Banana } \\
\text { cultivar }\end{array}$} & \multicolumn{3}{|c|}{$\mathrm{BPH}(\mathrm{m})$} & \multicolumn{3}{|c|}{$\mathrm{PD}(\mathrm{cm})$} & \multicolumn{3}{|c|}{ GLN } & \multicolumn{3}{|c|}{$\mathrm{HN}$} & \multicolumn{3}{|c|}{$\mathrm{FN}$} \\
\hline & Cycle 1 & Cycle 2 & $\overline{\text { Cycle } 3}$ & $\overline{\text { Cycle } 1}$ & Cycle 2 & Cycle 3 & Cycle 1 & Cycle 2 & Cycle 3 & Cycle 1 & Cycle 2 & Cycle 3 & Cycle 1 & Cycle 2 & Cycle 3 \\
\hline Pacovan Ken & $3.8 \mathrm{bA}$ & $4.7 \mathrm{~dB}$ & $5.6 \mathrm{dC}$ & $27.8 \mathrm{aA}$ & $34.2 \mathrm{bB}$ & $37.8 \mathrm{cC}$ & $14.3 \mathrm{bA}$ & $13.0 \mathrm{bA}$ & $10.3 \mathrm{aA}$ & $7.3 \mathrm{aA}$ & $8.3 \mathrm{bA}$ & $9.5 \mathrm{aB}$ & $113.6 \mathrm{aA}$ & $126.6 \mathrm{aA}$ & $156.8 \mathrm{aB}$ \\
\hline PV42-68 & $3.8 \mathrm{bA}$ & $5.3 \mathrm{~dB}$ & $6.0 \mathrm{dC}$ & $29.1 \mathrm{aA}$ & $35.1 \mathrm{bB}$ & $38.5 \mathrm{cC}$ & $12.8 \mathrm{bB}$ & $12.9 \mathrm{bB}$ & $9.1 \mathrm{aA}$ & $7.2 \mathrm{aA}$ & $8.1 \mathrm{bA}$ & $9.0 \mathrm{aB}$ & $104.4 \mathrm{aA}$ & $124.9 \mathrm{aA}$ & $139.3 \mathrm{aA}$ \\
\hline BRS Vitória & $4.0 \mathrm{bA}$ & $4.5 \mathrm{cA}$ & $5.7 \mathrm{~dB}$ & $28.5 \mathrm{aA}$ & $31.6 \mathrm{aB}$ & $35.3 \mathrm{cC}$ & $12.9 \mathrm{bB}$ & $12.0 \mathrm{bB}$ & $9.0 \mathrm{aA}$ & $7.1 \mathrm{aA}$ & $8.6 \mathrm{bB}$ & $8.8 \mathrm{aB}$ & $107.3 \mathrm{aA}$ & $128.9 \mathrm{aA}$ & 137.1aA \\
\hline BRS Japira & $4.0 \mathrm{bA}$ & $4.9 \mathrm{~dB}$ & $6.0 \mathrm{dC}$ & $27.9 \mathrm{aA}$ & $32.4 \mathrm{bB}$ & $38.6 \mathrm{cC}$ & $14.4 \mathrm{bA}$ & $14.0 \mathrm{bA}$ & $8.9 \mathrm{aA}$ & $7.5 \mathrm{aA}$ & $8.4 \mathrm{bA}$ & $8.8 \mathrm{aA}$ & $110.9 \mathrm{aA}$ & $126.8 \mathrm{aA}$ & $130.0 \mathrm{aA}$ \\
\hline BRS Preciosa & $3.7 \mathrm{bA}$ & $4.3 \mathrm{cB}$ & $5.8 \mathrm{dC}$ & $26.7 \mathrm{aA}$ & $33.0 \mathrm{bB}$ & $38.3 \mathrm{cC}$ & $11.8 \mathrm{aA}$ & $11.0 \mathrm{aA}$ & $9.9 \mathrm{aA}$ & $6.8 \mathrm{aA}$ & $8.7 \mathrm{bB}$ & $8.9 \mathrm{aB}$ & $98.3 \mathrm{aA}$ & $137.8 \mathrm{aB}$ & $140.9 \mathrm{aB}$ \\
\hline BRS Garantida & $3.6 \mathrm{bA}$ & $4.4 \mathrm{cB}$ & $5.8 \mathrm{dC}$ & $24.9 \mathrm{aA}$ & $31.6 \mathrm{aB}$ & $38.1 \mathrm{cB}$ & $12.3 \mathrm{bB}$ & $10.3 \mathrm{aA}$ & $9.8 \mathrm{aA}$ & $6.6 \mathrm{aA}$ & $7.0 \mathrm{aA}$ & $8.3 \mathrm{aB}$ & $88.9 \mathrm{aA}$ & $111.4 \mathrm{aB}$ & $124.9 \mathrm{aB}$ \\
\hline Thap Maeo & $3.5 \mathrm{bA}$ & $3.7 \mathrm{bA}$ & $5.1 \mathrm{cB}$ & $27.2 \mathrm{aA}$ & $30.2 \mathrm{aA}$ & $37.1 \mathrm{cB}$ & $11.7 \mathrm{aA}$ & $11.9 \mathrm{bA}$ & $12.1 \mathrm{aA}$ & $11.3 \mathrm{cA}$ & $12.9 \mathrm{~dB}$ & $15.8 \mathrm{dC}$ & $204.0 \mathrm{cA}$ & $237.3 \mathrm{cB}$ & $278.7 \mathrm{dC}$ \\
\hline BRS Tropical & $3.7 \mathrm{bA}$ & $3.9 \mathrm{bA}$ & $4.3 \mathrm{bB}$ & $33.6 \mathrm{bA}$ & $33.8 \mathrm{bA}$ & $33.8 \mathrm{cA}$ & $13.2 \mathrm{bB}$ & $11.9 \mathrm{bB}$ & $9.0 \mathrm{aA}$ & $7.3 \mathrm{aB}$ & $7.2 \mathrm{aB}$ & $7.6 \mathrm{aB}$ & $134.3 \mathrm{bA}$ & $132.2 \mathrm{aA}$ & $137.8 \mathrm{aA}$ \\
\hline BRS Platina & $2.9 \mathrm{aA}$ & $3.7 \mathrm{bB}$ & $4.1 \mathrm{bB}$ & $26.9 \mathrm{aA}$ & $33.3 \mathrm{bB}$ & $37.0 \mathrm{cC}$ & $11.8 \mathrm{aA}$ & $11.2 \mathrm{aA}$ & $10.2 \mathrm{aA}$ & $8.2 \mathrm{bA}$ & $9.1 \mathrm{bA}$ & $10.8 \mathrm{bB}$ & $120.3 \mathrm{aA}$ & $140.3 \mathrm{aA}$ & $178.5 \mathrm{bB}$ \\
\hline BRS Maravilha & $2.8 \mathrm{aA}$ & $3.4 \mathrm{bB}$ & $4.3 \mathrm{bC}$ & $26.0 \mathrm{aA}$ & $32.5 \mathrm{bB}$ & $37.5 \mathrm{cC}$ & $10.3 \mathrm{aA}$ & $8.9 \mathrm{aA}$ & $9.3 \mathrm{aA}$ & $10.2 \mathrm{cA}$ & $10.8 \mathrm{cA}$ & $12.1 \mathrm{cB}$ & $153.3 \mathrm{bA}$ & $182.8 \mathrm{bB}$ & $213.2 \mathrm{cC}$ \\
\hline FHIA 02 & $2.6 \mathrm{aA}$ & $3.6 \mathrm{bB}$ & $4.2 \mathrm{bC}$ & $25.9 \mathrm{aA}$ & $33.2 \mathrm{bB}$ & $36.0 \mathrm{cB}$ & $10.2 \mathrm{aA}$ & $10.3 \mathrm{aA}$ & $8.8 \mathrm{aA}$ & $10.3 \mathrm{cA}$ & $11.2 \mathrm{cB}$ & $12.1 \mathrm{cB}$ & $155.6 \mathrm{bA}$ & $179.3 \mathrm{bA}$ & $217.8 \mathrm{cB}$ \\
\hline FHIA 18 & $2.8 \mathrm{bA}$ & $3.5 \mathrm{bB}$ & $4.2 \mathrm{bC}$ & $26.1 \mathrm{aA}$ & $32.3 \mathrm{bB}$ & $36.4 \mathrm{cC}$ & $10.6 \mathrm{aA}$ & $10.0 \mathrm{aA}$ & $9.9 \mathrm{aA}$ & $10.0 \mathrm{cA}$ & $10.5 \mathrm{cA}$ & $13.2 \mathrm{cB}$ & $152.3 \mathrm{bA}$ & $175.2 \mathrm{bA}$ & $226.6 \mathrm{cB}$ \\
\hline Galil 18 & $3.2 \mathrm{aA}$ & $4.1 \mathrm{cB}$ & $4.1 \mathrm{bB}$ & $32.6 \mathrm{bA}$ & $36.7 \mathrm{bB}$ & $36.7 \mathrm{cB}$ & $10.8 \mathrm{aA}$ & $10.9 \mathrm{aA}$ & $10.9 \mathrm{aA}$ & $10.1 \mathrm{cA}$ & $10.8 \mathrm{cA}$ & $12.0 \mathrm{cB}$ & $167.8 \mathrm{bA}$ & $164.8 \mathrm{bA}$ & $180.0 \mathrm{bA}$ \\
\hline Buccaneer & $2.8 \mathrm{aA}$ & $3.7 \mathrm{bB}$ & $4.2 \mathrm{bC}$ & $28.1 \mathrm{aA}$ & $35.3 \mathrm{bB}$ & $36.2 \mathrm{cC}$ & $10.3 \mathrm{aA}$ & $11.9 \mathrm{bA}$ & $9.8 \mathrm{aA}$ & $8.0 \mathrm{bA}$ & $11.0 \mathrm{cB}$ & $12.4 \mathrm{cC}$ & $138.1 \mathrm{bA}$ & $210.3 \mathrm{cB}$ & $210.8 \mathrm{cB}$ \\
\hline Caipira & $2.7 \mathrm{aA}$ & $3.3 \mathrm{aB}$ & $3.9 \mathrm{bC}$ & $25.2 \mathrm{aA}$ & $29.8 \mathrm{aB}$ & $29.3 \mathrm{bB}$ & $10.5 \mathrm{aA}$ & $12.3 \mathrm{bB}$ & $9.8 \mathrm{aA}$ & $8.4 \mathrm{bA}$ & $10.0 \mathrm{cB}$ & $10.5 \mathrm{bB}$ & $178.8 \mathrm{cA}$ & $225.6 \mathrm{cB}$ & $238.9 \mathrm{cB}$ \\
\hline Pacovan & $3.6 \mathrm{bA}$ & $4.1 \mathrm{cA}$ & $5.7 \mathrm{~dB}$ & $24.3 \mathrm{aA}$ & $30.3 \mathrm{aB}$ & $35.3 \mathrm{cC}$ & $11.2 \mathrm{aA}$ & $13.4 \mathrm{bB}$ & $10.5 \mathrm{aA}$ & $7.9 \mathrm{bA}$ & $8.0 \mathrm{bA}$ & $9.3 \mathrm{aA}$ & $110.3 \mathrm{aA}$ & $114.9 \mathrm{aA}$ & $139.3 \mathrm{aA}$ \\
\hline Prata Anã & $2.6 \mathrm{aA}$ & $3.6 \mathrm{bB}$ & $3.2 \mathrm{aB}$ & $26.8 \mathrm{aA}$ & $32.3 \mathrm{bB}$ & $29.9 b B$ & $11.7 \mathrm{aB}$ & $14.0 \mathrm{bC}$ & $7.8 \mathrm{aA}$ & $9.3 \mathrm{cA}$ & $10.1 \mathrm{cA}$ & $9.6 \mathrm{aA}$ & $148.8 \mathrm{bA}$ & $170.3 \mathrm{bA}$ & $149.4 \mathrm{aA}$ \\
\hline Williams & $2.5 \mathrm{aA}$ & $3.0 \mathrm{aA}$ & $3.1 \mathrm{aA}$ & $25.8 \mathrm{aA}$ & $29.4 \mathrm{aB}$ & $26.6 \mathrm{aA}$ & $9.8 \mathrm{aA}$ & $10.0 \mathrm{aA}$ & $11.1 \mathrm{aA}$ & $8.0 \mathrm{bA}$ & $11.0 \mathrm{cB}$ & $10.4 \mathrm{bB}$ & $148.8 \mathrm{bA}$ & $205.6 \mathrm{cB}$ & 183.6bB \\
\hline Grande Naine & $2.5 \mathrm{aA}$ & $2.9 \mathrm{aB}$ & $3.1 \mathrm{aB}$ & $26.6 \mathrm{aA}$ & $28.4 \mathrm{aA}$ & $31.2 \mathrm{bB}$ & $11.3 \mathrm{aA}$ & $11.0 \mathrm{aA}$ & 11.1aA & $8.3 \mathrm{bA}$ & $9.3 \mathrm{bA}$ & $12.1 \mathrm{cB}$ & $156.6 \mathrm{bA}$ & $168.9 \mathrm{bA}$ & $237.1 \mathrm{cB}$ \\
\hline
\end{tabular}

${ }^{(1)}$ Values followed by equal letters, lowercase in the columns and uppercase in the lines for each parameter, do not differ significantly by the Scott-Knott test, at $5 \%$ probability. 
productive areas, such as in the municipality of Urandi, in the state of Bahia (Donato et al., 2009), and in the municipality of Goiânia, in the state of Goiás, both in Brazil (Mendonça et al., 2013). At the region of Vale do Ribeira, in the state of São Paulo, Nomura et al. (2013) reported production periods ranging from 9.1 months, for the cultivar BRS Japira, to 13.8 months, for Caipira.

The fresh weights of fruits, hands, and bunches were also affected by the interaction between cultivars and cycles (Table 3). For bananas, a smaller size and lower weight are desirable, which were observed for the Thap Maeo, BRS Tropical, and Caipira cultivars, especially in the first two cycles. The shape of the fruits of the resistant cultivars is similar to that of the Maçã and Prata Anã bananas, which are preferred in the domestic consumer market (Matsuura et al., 2004). During the first cycle, large and heavy bunches were obtained with the BRS Platina, BRS Maravilha, FHIA 02, FHIA 18, Galil 18, and Buccaneer cultivars, which also showed good yield potential in the other cycles, and with banana plants derived from Pacovan, which were not recommended because of their height.

The choice of the most adequate cultivar by farmers naturally depends on their production goals and targets. However, considering the planting density used of 1,333 plants per hectare, a high production of bananas may be expected, ranging from $39.3 \mathrm{Mg}$ ha${ }^{1}$, for the BRS Maravilha cultivar (first crop cycle), to $50.2 \mathrm{Mg} \mathrm{ha}^{-1}$, for FHIA 02 (second cycle). Regarding high productive potential, the Buccaneer cultivar should also be considered, since it produced up to $41 \mathrm{Mg} \mathrm{ha}^{-1}$ in the first cycle and $47.5 \mathrm{Mg} \mathrm{ha}^{-1}$ in the third one, being an alternative to the Williams and Grande Naine cultivars, which are sensitive to BLSD and produce bananas with a similar shape (Lédo et al., 2008). Despite this, in the regional consumer market, there is still uncertainty on the intention of buying 'Buccanero' banana (Garruti et al., 2013), showing that it could be tested in new products and markets.

The cluster analysis according to the AHC enabled the formation of four major clusters with the assessed bananas (Figure 1). The first cluster consisted of only one cultivar, Thap Maeo, from the Mysore subgroup. The second cluster was formed by the Caipira and BRS Tropical cultivars from the Ibota and Prata subgroups, respectively, and by Prata Anã. The third cluster was the largest, with the following cultivars: Williams and Grande Naine, both from the Cavendish

Table 3. Period from planting to harvest, as well as fresh weight of hands (HW), of fruits (FW), and of bunches without stalks (BW) of the banana (Musa spp.) cultivars planted at the Frutacor farm, in the municipality of Limoeiro do Norte, in the state of Ceará, Brazil(1).

\begin{tabular}{|c|c|c|c|c|c|c|c|c|c|c|c|c|}
\hline \multirow{2}{*}{$\begin{array}{l}\text { Banana } \\
\text { cultivar }\end{array}$} & \multicolumn{3}{|c|}{ Period until harvest } & \multicolumn{3}{|c|}{$\mathrm{HW}(\mathrm{kg})$} & \multicolumn{3}{|c|}{ FW (g) } & \multicolumn{3}{|c|}{$\mathrm{BW}(\mathrm{kg})$} \\
\hline & Cycle 1 & Cycle 2 & Cycle 3 & Cycle 1 & Cycle 2 & Cycle 3 & Cycle 1 & Cycle 2 & ycle 3 & Cycle 1 & Cycle 2 & Cycle 3 \\
\hline Pacovan Ken & $282.9 \mathrm{bA}$ & $2.2 \mathrm{bB}$ & $599.3 \mathrm{bC}$ & $3.0 \mathrm{cA}$ & $3.0 \mathrm{cA}$ & $7 \mathrm{bA}$ & $190.9 \mathrm{bA}$ & $194.4 \mathrm{bA}$ & $7.1 \mathrm{cA}$ & $21.7 \mathrm{cA}$ & $24.6 \mathrm{cA}$ & $6.0 \mathrm{cA}$ \\
\hline PV42-68 & $99.0 \mathrm{bA}$ & $447.2 \mathrm{bB}$ & $600.3 \mathrm{bC}$ & $3.2 \mathrm{cB}$ & $.7 \mathrm{cA}$ & $7 \mathrm{bA}$ & $22.3 \mathrm{cB}$ & $175.7 \mathrm{bA}$ & $81.2 \mathrm{cA}$ & $23.3 \mathrm{cA}$ & $1.9 \mathrm{bA}$ & $4.4 \mathrm{bA}$ \\
\hline tória & $271.0 \mathrm{aA}$ & $431.8 \mathrm{bB}$ & $604.6 \mathrm{bC}$ & $\mathrm{cA}$ & $9 \mathrm{cA}$ & & $194.0 \mathrm{bA}$ & $195.1 \mathrm{bA}$ & & & $25.1 \mathrm{cA}$ & $1 \mathrm{bA}$ \\
\hline RS J & $299.0 \mathrm{bA}$ & $431.3 \mathrm{bB}$ & $619.6 \mathrm{bC}$ & $3.5 \mathrm{~dB}$ & $3.0 \mathrm{cA}$ & $2.9 \mathrm{bA}$ & $239.1 \mathrm{cB}$ & $195.2 \mathrm{bA}$ & $194.7 \mathrm{cA}$ & $26.5 \mathrm{dA}$ & $24.8 \mathrm{cA}$ & $5.3 \mathrm{bA}$ \\
\hline ciosa & $262.0 \mathrm{aA}$ & $422.9 \mathrm{bB}$ & $605.0 \mathrm{bC}$ & & $.5 \mathrm{bA}$ & $.6 \mathrm{bA}$ & $187.3 \mathrm{bA}$ & $157.3 \mathrm{bA}$ & $\mathrm{cA}$ & & & $9 \mathrm{bA}$ \\
\hline RS Garantida & $262.0 \mathrm{aA}$ & $401.8 \mathrm{aB}$ & $612.1 \mathrm{bC}$ & & $3.0 \mathrm{cB}$ & & $200.2 \mathrm{bB}$ & $191.7 \mathrm{bB}$ & $136.7 \mathrm{bA}$ & & $20.8 \mathrm{bA}$ & $17.2 \mathrm{aA}$ \\
\hline Thap & $268.7 \mathrm{aA}$ & $399.3 \mathrm{aB}$ & $589.1 \mathrm{aC}$ & $2.1 \mathrm{aA}$ & $1 \mathrm{aA}$ & $\mathrm{A}$ & $118.4 \mathrm{aA}$ & $113.4 \mathrm{aA}$ & & & $\mathrm{cA}$ & $28.8 \mathrm{cA}$ \\
\hline DD & $298.3 \mathrm{bA}$ & $430.7 \mathrm{bB}$ & 587 & 1. & & & & $119.3 \mathrm{aA}$ & 12 & & & $16.9 \mathrm{aA}$ \\
\hline tina & $294.9 \mathrm{bA}$ & $411.3 \mathrm{aB}$ & $604.3 \mathrm{bC}$ & $3.6 \mathrm{~dB}$ & $2.8 \mathrm{cA}$ & $2.8 \mathrm{bA}$ & $247.5 \mathrm{cB}$ & $181.7 \mathrm{bA}$ & 170 & 30. & $A$ & $30.4 \mathrm{dA}$ \\
\hline BRS I & $262.0 \mathrm{aA}$ & $396.9 \mathrm{aB}$ & $577.3 \mathrm{aC}$ & & $3.0 \mathrm{cA}$ & & $192.4 \mathrm{bA}$ & $178.1 \mathrm{bA}$ & & & $32.5 \mathrm{dA}$ & $37.6 \mathrm{eB}$ \\
\hline FHIA 02 & $262.0 \mathrm{aA}$ & $390.8 \mathrm{aB}$ & $589.5 \mathrm{aC}$ & $3.0 \mathrm{cA}$ & $3.4 \mathrm{cA}$ & $2.8 \mathrm{bA}$ & 199.2bB & $212.2 \mathrm{bB}$ & 157 & $31.0 \mathrm{dA}$ & $37.7 \mathrm{eA}$ & $34.3 \mathrm{dA}$ \\
\hline FHIA 18 & $262.0 \mathrm{aA}$ & $393.3 \mathrm{aB}$ & $589.3 \mathrm{aC}$ & $3.0 \mathrm{cA}$ & $3.3 \mathrm{cA}$ & & $198.4 \mathrm{bA}$ & $194.6 \mathrm{bA}$ & $183.2 \mathrm{cA}$ & $30.2 \mathrm{dA}$ & $34.0 \mathrm{eA}$ & $41.5 \mathrm{eB}$ \\
\hline Galil 18 & $279.3 \mathrm{bA}$ & $390.8 \mathrm{aB}$ & $572.3 \mathrm{aC}$ & $3.1 \mathrm{cB}$ & $2.7 \mathrm{cA}$ & $2.4 \mathrm{aA}$ & $189.4 \mathrm{bA}$ & $180.4 \mathrm{bA}$ & $158.6 \mathrm{cA}$ & $31.8 \mathrm{dA}$ & $29.7 \mathrm{dA}$ & $28.6 \mathrm{cA}$ \\
\hline Buccaneer & $262.0 \mathrm{aA}$ & $433.6 \mathrm{bB}$ & $623.3 \mathrm{bC}$ & $3.8 \mathrm{~dB}$ & $2.9 \mathrm{cA}$ & $3.0 \mathrm{bA}$ & $223.0 \mathrm{cB}$ & $154.3 \mathrm{bA}$ & $184.7 \mathrm{cA}$ & $30.8 \mathrm{dA}$ & $32.5 \mathrm{dA}$ & $37.1 \mathrm{eB}$ \\
\hline Caipira & $298.5 \mathrm{bA}$ & $416.3 \mathrm{bB}$ & $587.9 \mathrm{aC}$ & $2.1 \mathrm{aA}$ & $2.0 \mathrm{aA}$ & $2.7 \mathrm{bB}$ & $98.5 \mathrm{aA}$ & $89.4 \mathrm{aA}$ & $118.8 \mathrm{aA}$ & $17.6 \mathrm{bA}$ & $20.2 \mathrm{bA}$ & $27.8 \mathrm{cB}$ \\
\hline & & $419.8 \mathrm{bB}$ & & & & & & & & & & \\
\hline Prata Anã & $271.2 \mathrm{aA}$ & $421.8 \mathrm{bB}$ & $589.0 \mathrm{aC}$ & $2.1 \mathrm{aA}$ & $2.2 \mathrm{aA}$ & $1.8 \mathrm{aA}$ & $130.5 \mathrm{aA}$ & $128.7 \mathrm{aA}$ & $114.6 \mathrm{aA}$ & $19.4 \mathrm{bA}$ & $21.9 \mathrm{bA}$ & $17.2 \mathrm{aA}$ \\
\hline Williams & $262.0 \mathrm{aA}$ & $427.4 \mathrm{bB}$ & $600.1 \mathrm{bC}$ & $4.0 \mathrm{dC}$ & $3.1 \mathrm{cB}$ & & $216.2 \mathrm{cB}$ & $166.1 \mathrm{bA}$ & $146.7 \mathrm{bA}$ & $32.2 \mathrm{~dB}$ & $34.2 \mathrm{eB}$ & $27.0 \mathrm{cA}$ \\
\hline Grande Naine & $262.0 \mathrm{aA}$ & $419.3 \mathrm{bB}$ & $600.1 \mathrm{bC}$ & $3.7 \mathrm{~dB}$ & $3.2 \mathrm{cA}$ & $2.9 \mathrm{bA}$ & 199.2bB & $174.7 \mathrm{bB}$ & $147.6 \mathrm{bA}$ & $31.2 \mathrm{dA}$ & $29.5 \mathrm{dA}$ & $35.0 \mathrm{dA}$ \\
\hline
\end{tabular}

(1)Values followed by equal letters, lowercase in the columns and uppercase in the lines for each parameter, do not differ significantly by the Scott-Knott test, at $5 \%$ probability. 
subgroup; Buccaneer, from the Gros Michel subgroup; FHIA 02, FHIA 18, and Galil 18; and BRS Maravilha and BRS Platina. The fourth cluster consisted of the Pacovan cultivar and of its hybrids BRS Preciosa, BRS Vitória, PV42-68, BRS Japira, Pacovan Ken, as well as of BRS Garantida, a hybrid derived from Prata São Tomé. The formation of clusters was not an exact match to the genomic groups of banana plants. The major groups were identified mainly with tetraploid materials, whereas the small groups were formed by triploid materials (Table 1). The latter genomic group possibly shows a greater divergence regarding plant growth and production of bunches that could be further explored in future works on breeding for new resistant hybrids with desirable traits for the banana crop.

PCA was also performed using the same matrix of multivariate data (Figure 2), which consisted of the means of the three production cycles of each variable. The first two components explained $70.9 \%$ of the total variance observed among the data. In the graphical analysis, the variables are represented by vectors that show the increase in the variable's intensity, while the samples are placed in the region of the graph next to the variables that characterize them. The length of vector decomposition in each component emphasizes its importance in the component, which helps to explain the differences between the samples that were observed

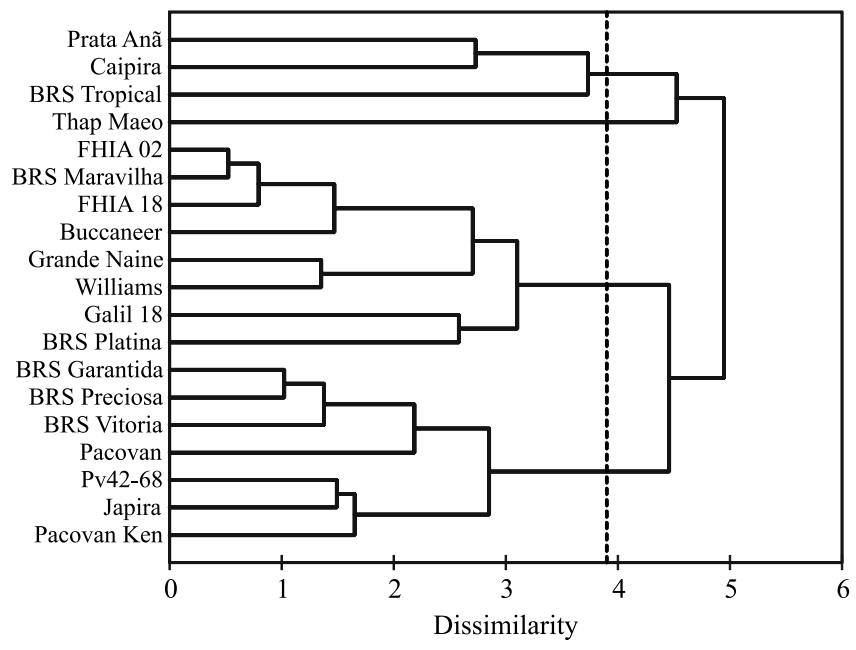

Figure 1. Dendrogram constructed by the cluster analysis (UPGMA) of banana (Musa spp.) cultivars planted at the Frutacor farm, in the municipality of Limoeiro do Norte, in the state of Ceará, Brazil. Dissimilarity generated with the average values of the agronomic variables evaluated during the three production cycles. in the present study. In the first component (F1) the cultivars were distinguished from each other according to growth, whereas, in the second one (F2), they were differentiated in terms of the size of the banana plants.

The most important variables in F1, with a significant coefficient of correlation, were number of hands, number of fingers in the hand, fresh weight of the bunch, height or length of the pseudostem, number of green leaves, and cycle or period from planting in the field until harvest of the first bunch. In F2, the most important variables with high positive correlation were fresh fruit and hand weight (Table 4). In this way, it was possible to visualize four distinct groups, very similar to those obtained by the cluster analysis. The Pacovan, Pacovan Ken, PV42-68, BRS Vitória, BRS Japira, and BRS Preciosa cultivars were grouped on the negative side of F1, predominantly in the upper quadrant (Figure 2), and were characterized as being tall, having a larger pseudostem diameter, and presenting a low production potential compared with the other cultivars. The BRS Garantida cultivar showed

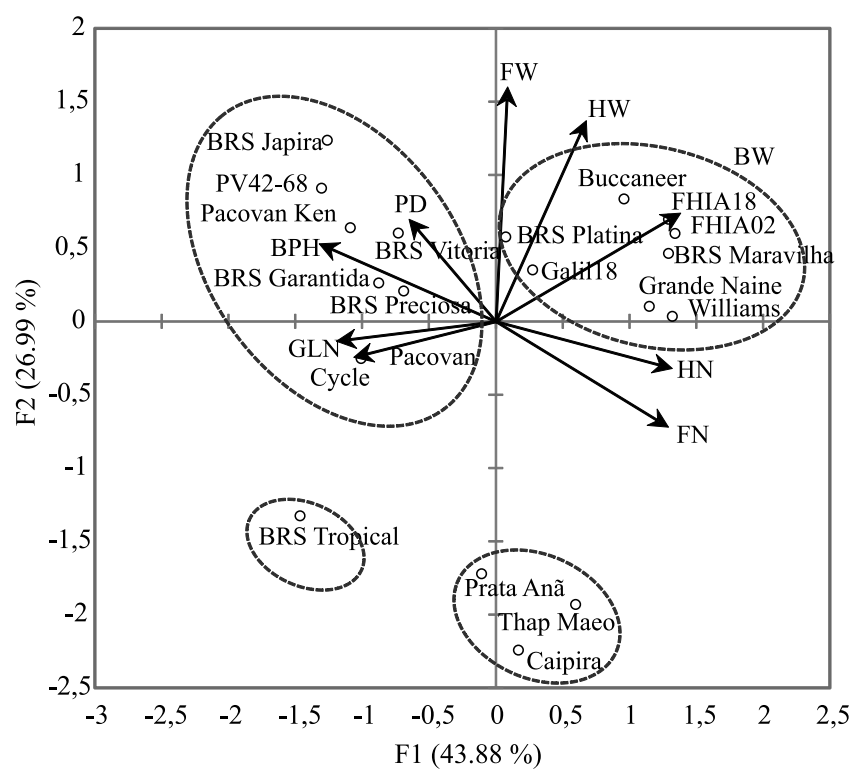

Figure 2. Principal component analysis with average values from the three production cycles for: banana (Musa spp.) plant height from the ground up to the point of emission of the bunch $(\mathrm{BPH})$; diameter of the base of the pseudostem (PD); fresh weight of fruits (FW), of hands (HW), and of bunches without stalks (BW); number of hands (HN) and of fruits in the bunch (FN); number of days from planting to harvest of the first bunch (Cycle); and number of green leaves in the flowering phase (GLN). F1, first component; and $\mathrm{F} 2$, second component. 
growth and production that were very close to those observed for BRS Preciosa and Pacovan. However, both the BRS Garantida and BRS Preciosa cultivars had a shorter first cycle, in comparison with Pacovan.

The BRS Platina and BRS Maravilha cultivars, both derived from Prata Anã, resembled the FHIA genotypes and the cultivars of the Cavendish subgroup, all with low height and high productivity. The Buccaneer cultivar showed a profile that was quite similar to that of small-sized clusters. 'BRS Tropical', 'Prata Anã', 'Thap Maeo', and 'Caipira' were allocated at the bottom part of the graph (Figure 2) on the opposite side of the vectors of fresh hand and finger weight, since the produced bananas were small and similar to those of the Maçã cultivar.

The combined use of AHC, Pearson's correlation, and PCA provided an adequate explanation for the nature of the growth and the production of the banana genotypes and should be used as a basis for the selection of more appropriate cultivars to be cultivated in semiarid regions, according to the desirable agromorphological traits. Based on the obtained results, it became clear that cultivars derived from Pacovan keep the agronomic traits of this female genitor. However, banana cultivars from crossbreeding with Prata Anã may differ in growth and in production of bunches, when compared with their progenitor plant. The latter genotypes maintain phenotypic traits that are similar to those of the FHIA hybrids from the Cavendish subgroup and of the Buccaneer cultivar.

Table 4. Correlation matrix among the studied variables of banana (Musa spp.) cultivars planted at the Frutacor farm, in the municipality of Limoeiro do Norte, in the state of Ceará, Brazil ${ }^{(1)}$.

\begin{tabular}{lccccccccc}
\hline Variables & PD & BPH & GLN & HN & FN & BW & FW & HW & Cycle \\
\hline PD & - & $\underline{0.58}$ & 0.22 & -0.12 & -0.35 & -0.06 & 0.30 & 0.03 & 0.22 \\
BPH & & - & $\underline{0.62}$ & $\underline{-0.54}$ & $\underline{-0.69}$ & $\underline{-0.51}$ & 0.27 & -0.15 & 0.38 \\
GLN & & & - & -0.39 & -0.37 & $\underline{-0.54}$ & -0.09 & -0.28 & $\underline{0.58}$ \\
HN & & & & - & $\underline{0.89}$ & $\underline{0.71}$ & -0.15 & 0.08 & -0.43 \\
FN & & & & & - & $\underline{0.57}$ & -0.41 & -0.02 & -0.30 \\
BW & & & & & & - & $\underline{0.49}$ & $\underline{0.75}$ & $\underline{-0.48}$ \\
FW & & & & & & & - & $\underline{0.86}$ & -0.16 \\
HW & & & & & & & & - & -0.27 \\
Cycle & & & & & & & & & -
\end{tabular}

(1)Values underlined represent significant correlations by the least significant difference t-test, at 5\% probability. $\mathrm{PD}$, pseudostem diameter; $\mathrm{BPH}$, banana plant height; GLN, number of green leaves at the flowering stage; $\mathrm{HN}$, number of hands in the bunch; FN, number of fruits in the bunch; BW, fresh weight of bunches; FW, fresh weight of fruits; HW, fresh weight of hands; and Cycle, number of days from planting to harvest.

\section{Conclusions}

1. The 'Maçã' banana (Musa spp.) cultivar is unsuitable for planting in irrigated soil due to its susceptibility to Fusarium wilt and it can be replaced by Caipira and BRS Tropical, which are resistant to Fusarium oxysporum f. sp. cubense and black leaf streak disease (BLSD) and also present high potential productivity.

2. The Pacovan Ken, PV42-68, BRS Vitoria, BRS Japira, BRS Preciosa, BRS Garantida, and Thap Maeo cultivars are too tall to be planted on plateaus unprotected from winds.

3. The BRS Maravilha, BRS Platina, FHIA 02, FHIA 18, and Galil 18 cultivars are alternatives to Pacovan, Prata Anã, and Maçã, which are susceptible to BLSD.

4. The Buccaneer cultivar is short and has good productive potential, which means it could be an alternative to the susceptible cultivars belonging to the Cavendish subgroup.

\section{Acknowledgments}

To Banco do Nordeste do Brasil (BNB) and to Frutacor farm, for financial support; and to Dr. Fernando Antonio de Souza Aragão, for assisting in the statistical analysis.

\section{References}

ABDI, H.; WILLIAMS, L.J. Principal component analysis. Wiley Interdisciplinary Reviews: Computational Statistics, v.2, p.433459, 2010. DOI: 10.1002/wics.101.

AZEVEDO, V.F. de; DONATO, S.L.R.; ARANTES. A. de M.; MAIA, V.M.; SILVA, S. de O. e. Avaliação de bananeiras tipo Prata, de porte alto, no semiárido. Ciência e Agrotecnologia, v.34, p.1372-1380, 2010. DOI: 10.1590/S1413-70542010000600003.

BORGES, A.L.; SILVA, A.L. da; BATISTA, D. da C.; MOREIRA, F.R.B.; FLORI, J.E.; OLIVEIRA, J.E. de M.; ARAÚJO, J.L.P.; PINTO, J.M.; CASTRO, J.M. da C. e; MOURA, M.S.B. de; AZOUBEL, P.M.; CUNHA, T.J.F.; SILVA, S. de O. e; CORDEIRO, Z.J.M. Sistema de produção da bananeira irrigada. 2009. (Embrapa Semiárido. Sistemas de produção, 4). Available at: $<$ https://www.infoteca.cnptia.embrapa.br/infoteca/bitstream/ doc/662460/1/SistemadeProducaodaBananeiraIrrigada.pdf $>$. Accessed on: June 32016.

CARVALHO, A.V.; SECCADIO, L.L.; MOURÃO JÚNIOR, M.; NASCIMENTO, W.M.O. do. Qualidade pós-colheita de cultivares de bananeiras do grupo 'Maçã', na região de Belém-PA. Revista Brasileira de Fruticultura, v.33, p.1095-1102, 2011. DOI: 10.1590/ S0100-29452011000400007.

CHURCHILL, A.C.L. Mycosphaerella fijiensis, the black leaf streak pathogen of banana: progress towards understanding 
pathogen biology and detection, disease development, and the challenges of control. Molecular Plant Pathology, v.12, p.307-328, 2011. DOI: 10.1111/j.1364-3703.2010.00672.x.

COSTA, F. da S.; COELHO, E.F.; BORGES, A.L.; PAMPONET, A.J.M.; SILVA, A. dos A.S.M. da; AZEVEDO, N.F. de. Crescimento, produção e acúmulo de potássio em bananeira 'Galil 18' sob irrigação e fertilização potássica. Pesquisa Agropecuária Brasileira, v.47, p.409-416, 2012. DOI: 10.1590/S0100-204X2012000300013.

CUNHA C.M.S.; HINZ, R.H.; PEREIRA, A.; TCACENCO, F.A.; PAULINO, E.C.; STADNIK, M.J. A SCAR marker for identifying susceptibility to Fusarium oxysporum f. sp. cubense in banana. Scientia Horticulturae, v.191, p.108-112, 2015. DOI: 10.1016/j. scienta.2015.04.038.

DNOCS. Departamento Nacional de Obras Contra as Secas. Perímetro irrigado Jaguaribe-Apodi. Available at: <http:// www.dnocs.gov.br/ dnocs/doc/canais/perimetros_irrigados/ce/ jaguaribe_apodi.html>. Accessed on: June 32016.

DONATO, S.R.L.; ARANTES, A. de M.; SILVA, S. de O. e; CORDEIRO, Z.J.M. Comportamento fitotécnico da bananeira 'Prata Anã' e de seus híbridos. Pesquisa Agropecuária Brasileira, v.44, p.1608-1615, 2009. DOI: 10.1590/S0100-204X2009001200007.

FAO. Food and Agriculture Organization of the United Nations Faostat: Production in 2012. Rome. Available at: $<$ http://faostat.fao. org/site/567/DesktopDefault.aspx?PageID=567\#ancor $>$. Accessed on: June 32016.

FLORI, J.E.; RESENDE, G.M. de; PAIVA, L.E. Produção de bananeira 'Grande Naine' superadensada e irrigada no vale do São Francisco. Ciência e Agrotecnologia, v.28, p.1060-1065, 2004. DOI: $10.1590 /$ S1413-70542004000500013.

GARRUTI, D. dos S.; MATIAS, M. de L.; FACUNDO, H.V. de V.; SILVA, E. de O.; COSTA, J.N. da; SILVA, M.A.A.P. da. Aceitação de cultivares de bananas resistentes à Sigatoka Negra junto ao consumidor da região Nordeste do Brasil. Ciência Rural, v.42, p.948-954, 2012.

GARRUTI, D. S.; PEREIRA, G.S.; WEBER, O.B.; COSTA, J.N. da; FACUNDO, H.V.V. Acceptance of banana cultivars resistant to black leaf streak by consumers of Brazilian Northeast region. Acta Horticulturae, v.986, p.345-351，2013. DOI: 10.17660/ ActaHortic.2013.986.37.

GASPAROTTO, L.; PEREIRA, J.C.R.; HANADA, R.E.; MONTARROYOS, A.V.V. Sigatoka-negra da bananeira. Manaus: Embrapa Amazônia Ocidental, 2006. 177p.

GHINI, R.; HAMADA, E.; GONÇALVES, R.R.V.; GASPAROTTO, L.; PEREIRA, J.C.R. Análise de risco das mudanças climáticas globais sobre a sigatoka-negra da bananeira no Brasil. Fitopatologia Brasileira, v.32, p.197-204, 2007. DOI: 10.1590/S0100-41582007000300003.

IBGE. Instituto Brasileiro de Geografia e Estatística. Banco de Dados Agregados. Sistema IBGE de Recuperação Automática SIDRA. Produção. 2015. Available at: <http://www.sidra.ibge.gov. $\mathrm{br} / \mathrm{bda} /$ agric/default.asp? $\mathrm{t}=2 \& \mathrm{z}=\mathrm{t} \& \mathrm{o}=11 \& \mathrm{u} 1=1 \& \mathrm{u} 2=1 \& \mathrm{u} 3=1 \& \mathrm{u} 4=$ $1 \& u 5=1 \& u 6=1>$. Accessed on: June 32016.

JESUS JÚNIOR, W.C. de; WALADARES JÚNIOR, R.; CECÍLIO, R.A.; MORAES, W.B.; VALE, F.X.R. do; ALVES, F.R.; PAUL, P.A. Worldwide geographical distribution of Black Sigatoka for banana: predictions based on climate change models. Scientia Agricola, v.65, p.40-53, 2008. Special issue.

JESUS, O.N. de; SILVA, S. de O. e; AMORIM, E.P.; FERREIRA, C.F.; CAMPOS, J.M.S. de; SILVA, G. de Genetic diversity and population structure of Musa accessions in ex situ conservation. BMC Plant Biology, v.13, p.1-22, 2013. DOI: 10.1186/1471-222913-41.

LÉDO, A. da S., SILVA JUNIOR, J.F. da; LÉDO, C.A. da S.; SILVA, S. de O. e. Avaliação de genótipos de bananeira na região do Baixo São Francisco, Sergipe. Revista Brasileira de Fruticultura, v.30, p.691-695, 2008. DOI: 10.1590/S0100-29452008000300022.

MATSUURA, F.C.A.U.; COSTA, J.I.P. da; FOLEGATTI, M.I. da S. Marketing de banana: preferências do consumidor quanto aos atributos de qualidade dos frutos. Revista Brasileira de Fruticultura, v.21, p.48-52, 2004. DOI: 10.1590/S010029452004000100014.

MENDONÇA, K.H., DUARTE, D.A. dos S., COSTA, V.A. de M.; MATOS, G.R.; SELEGUINI, A. Avaliação de genótipos de bananeira em Goiânia, estado de Goiás. Revista Ciência Agronômica, v.44, p.652-660, 2013. DOI: 10.1590/S180666902013000300030.

NOMURA, E.S., DAMATTO JUNIOR, E.R.; FUZITANI, E.J.; AMORIM, E.P.; SILVA, S. de O. e. Avaliação agronômica de genótipos de bananeiras em condições subtropicais, Vale do Ribeira, São Paulo - Brasil. Revista Brasileira de Fruticultura, v.35, p.112-122, 2013. DOI: 10.1590/S0100-29452013000100014.

PLOETZ, R.C. Management of Fusarium wilt of banana: a review with special reference to tropical race 4. Crop Protection, v.73, p.715, 2015. DOI: 10.1016/j.cropro.2015.01.007.

ROBERT, S.; RAVIGNE, V.; ZAPATER, M.-F.; ABADIE, C.; CARLIER, J. Contrasting introduction scenarios among continents in the worldwide invasion of the banana fungal pathogen Mycosphaerella fijiensis. Molecular Ecology, v.21, p.1098-1114, 2012. DOI: 10.1111/j.1365-294X.2011.05432.x.

SILVA, F.C. da. (Ed.). Manual de análises químicas de solos, plantas e fertilizantes. 2.ed. rev. e ampl. Brasília: Embrapa, 2009. $627 \mathrm{p}$.

SILVA, G.F.; PAIXÃO, R.D.V.; QUEIROZ, C.B.; SANTANA, M.F.; SOUZA, A.; SOUSA, N.R.; HANADA, R.E.; GASPAROTTO, L. Genetic diversity of Mycosphaerella fijiensis in Brazil analyzed using an ERIC-PCR marker. Genetics and Molecular Research, v.13, p.7698-7707, 2014. DOI: 10.4238/2014.September.26.7.

SILVA, S. de O. e; AMORIM, E.P.; SANTOS-SEREJO, J.A. dos. Cultivares. In: FERREIRA, C.F.; SILVA, S. de O. e; AMORIM, E.P.; SANTOS-SEREJO, J.A. dos (Ed.). O agronegócio da banana. Brasília: Embrapa, 2015. p.137-170.

SILVA, S. de O. e; AMORIM, E.P.; SANTOS-SEREJO, J.A. dos; FERREIRA, C.F.; RODRIGUEZ, M.A.D. Melhoramento genético da bananeira: estratégias e tecnologias disponíveis. Revista Brasileira de Fruticultura, v.35, p.919-931, 2013. DOI: 10.1590/ S0100-29452013000300032.

SNEATH, P.H.A.; SOKAL, R.R. Numerical taxonomy: the principles and practice of numerical classification. San Francisco: W.H. Freeman, 1973. 573p.

Received on June 17, 2016 and accepted on November 10, 2016 